\title{
Analysis of Industrial Formwork Systems Supply Chain Using Value Stream Mapping
}

\author{
Taylan Terzioglu ${ }^{1}$, Gul Polat ${ }^{2}$, and Harun Turkoglu ${ }^{3}$ \\ ${ }^{1}$ Ph.D. Candidate, Department of Civil Engineering, Istanbul Technical University, Maslak, Istanbul, Turkey. \\ E-mail: terzioglu17@itu.edu.tr \\ ${ }^{2}$ Professor, Department of Civil Engineering, Istanbul Technical University, Maslak, Istanbul, Turkey. \\ E-mail: polatgu@itu.edu.tr (corresponding author). \\ ${ }^{3} \mathrm{Ph}$.D. Candidate, Department of Civil Engineering, Istanbul Technical University, Maslak, Istanbul, Turkey. \\ E-mail: hturkoglu@itu.edu.tr
}

Project and Production Management

Received May 4, 2021; revised July 13, 2021; accepted August 24, 2021

Available online September 15, 2021

\begin{abstract}
Reinforced concrete (RC) is used as the primary structural material in almost all construction projects worldwide, from infrastructure to building projects. Since formwork is an essential part of RC construction supply chain, it has a significant impact on the project performance. In the industrial formwork systems supply chain, the roles and responsibilities of the main stakeholders (e.g., engineer, contractor, formwork fabricator) at various phases of the project can be represented by different supply chain configurations (SCCs). The objectives of this study are to identify different SCCs for industrial formwork systems in the Turkish RC construction industry and to analyze the identified SCCs using value stream mapping (VSM) method, which is an effective and major lean tool for identifying and eliminating waste. For this purpose, first, three SCCs for industrial formwork systems have been identified, which are predominantly used in Turkey. Then, these configurations were analyzed through VSM method on an ongoing building project where $500 \mathrm{~m}^{2}$ of industrial wall formwork would be used as a real-life case study. The analysis results indicated that the SCC with the early involvement of the formwork fabricator (FWF) had higher performance than other SCCs, which is consistent with a lean construction approach.
\end{abstract}

Keywords: Industrial formwork systems, lean construction, supply chain, value stream mapping.

Copyright (C) Journal of Engineering, Project, and Production Management (EPPM-Journal).

DOI 10.32738/JEPPM-2022-0005

\section{Introduction}

Reinforced concrete (RC) is the most commonly used structural material in the construction industry around the world, as in Turkey, since it provides more flexibility, ease of handling, and economical solutions when compared to other materials (Hawkins et al., 2016). The main activities associated with the $\mathrm{RC}$ construction consist of the erection of formwork, the placement of rebar, the pouring of concrete, the curing of concrete, and the stripping of formwork (Nguyen and Nguyen, 2013). As formwork is central to all activities in $\mathrm{RC}$ construction, it may be the major cost factor that can be up to $60 \%$ of the unit cost of RC structures depending on the type of structure (Krawczyńska-Piechna, 2017) and can represent up to 15\% of the total construction cost (Ko et al., 2011). The cost of formwork can range from one-third to two-thirds of the cost of a building frame (Jarkas, 2017).

In $\mathrm{RC}$ construction, material and time wastes are common problems, which bring about poor productivity and performance (Vilventhan et al., 2019). As formwork is involved from the beginning to the end of RC construction, it is a significant part of its supply chain, which may have an effect on project performance, especially in terms of time and cost. The productivity and performance of the formwork-related activities can be improved through a lean construction approach. Value stream mapping (VSM) is a lean tool widely used in the literature to identify and reduce material and time waste in construction projects (Rosenbaum et al., 2014; Sudhakar et al., 2017; Yunus et al., 2018). VSM enables practitioners to map the flow of information and materials using a lean approach (Wang et al., 2020). VSM can also be used to visualize the formwork preparation process and identify the formwork-related activities as value-adding and non-value-adding activities, thus improving the productivity and performance of these activities (Samarakoon et al., 2016).

Formwork systems are mainly categorized as traditional and industrial. The traditional formwork system consists mostly of project-specific non-standard timber elements and plywood. Therefore, it has low safety attributes, low 
cycle time, and high material waste (Karke and Kumathekar, 2014). Industrial formwork system consists of modular, reusable and durable components made of different types of materials such as steel, aluminum, wooden, and polymer (Zayed and Mohamed 2014), thereby reducing material and time waste, eliminating unnecessary material movements, improving inventory management, and leading to a wellorganized working environment (Abou Ibrahim and Hamzeh, 2015). In addition, industrial formwork systems can be pre-assembled off-site and transported to the construction site under ready-to-use conditions, which may reduce construction time and increase schedule flexibility (Hawkins et al., 2016). Therefore, the industrial formwork system supply chain generally performs better than the traditional formwork system supply chain in terms of lead time (Terzioglu et al., 2019).

The roles and responsibilities of the main stakeholders in the industrial formwork system supply chain can be combined in different ways depending on the project delivery system, construction method, type of structure, and capacity of the stakeholder (e.g., technical, financial, managerial). For this reason, examination of the different possible industrial formwork systems supply chain configurations can help to improve the time, cost, quality, and safety performance. However, the interaction of roles and responsibilities between different stakeholders has mostly been neglected in the literature. Most of the former studies that focused on formwork engineering can be categorized into three main groups; (1) lean design of the formwork and its implementation on the construction site with a lean approach, (2) determination of the selection and constructability assessment criteria for the formwork, and (3) application of decision-making methods for the appropriate formwork selection. Although these studies significantly contributed to the existing body of knowledge, they do not consider the impacts of roles and responsibilities undertaken by different stakeholders on the time performance of the industrial formwork systems. The objective of this study is to fill this important knowledge gap.

This study aims to identify the industrial formwork system supply chain configurations (SCCs) in the Turkish $\mathrm{RC}$ construction industry and to analyze the time performance of these configurations. For this purpose, first, face-to-face interviews were conducted with practitioners in the Turkish RC construction industry. Then, site visits and field studies were performed to identify the most commonly preferred industrial formwork system SCCs in the Turkish RC construction industry. Thereafter, an ongoing building project in which an experienced contractor would utilize $500 \mathrm{~m}^{2}$ of industrial wall formwork was examined as a real-life case study. In this case study, different SCCs were analyzed using the VSM method, and the findings were presented and compared with each other.

\section{Literature Review}

Several studies have been carried out in formwork engineering to improve the productivity and performance of RC construction projects. Most of the previous studies focused on formwork engineering were grouped under three main topics: (1) lean design of the formwork and its implementation on the construction site with a lean approach (e.g., Ko and Kuo, 2019; Ko and Kuo, 2020), (2) determination of the selection and constructability assessment criteria for the formwork (e.g., KrawczynskaPiechna, 2016; Kannan and Santhi, 2018), and (3) application of decision-making methods for the appropriate formwork selection (e.g., Shin et al., 2012; Elbeltagi et al., 2012). This study aims to identify the industrial formwork system SCCs in the Turkish RC construction industry and to analyze the time performance of these configurations. Therefore, the objective of this literature review is not to summarize all the studies focused on formwork engineering in the literature but to summarize the studies using a lean approach.

Ko et al. (2011) first used Toyota's "4Ps" model in formwork engineering to minimize material and time waste using Toyota's lean principles and philosophy. Based on Ko et al. (2011)'s study, Ko and Kuo (2015) employed VSM to analyze non-value adding activities in the LFD production flow and to increase customer value by early detection of hidden problems resulting in waste and rework. Following this study, Ko and Kuo (2019) proposed a systematic method called lean formwork design (LFD), which integrates "concurrent design" and "system dynamics" into the formwork design process in order to reduce waste and increase efficiency in RC construction. The proposed method aims to improve the design value by reducing or eliminating design problems or errors in the early phases of the project. The effectiveness of the proposed method was validated using computer simulations (Ko and Kuo 2019).

Sudhakar et al. (2017) utilized VSM as a lean tool to determine the lead times and non-value-added times for rebar installation, formwork installation, and concrete pouring activities for RC column and slab processes. Rosenbaum et al. (2014) applied VSM to a case study to enhance project performance, taking into account on-site formwork assembly and disassembly times. Similar to Rosenbaum et al. (2014)'s study, Yunus et al. (2017) used VSM to identify and compare time waste of on-site and offsite prefabrication processes for industrial formwork systems. Barbosa et al. (2014) developed process maps of work and material flow throughout the installation of the formwork and investigated on-site safety risks for each formwork-related activity. Pheng et al. (2016) applied lean principles to reduce time and material waste in the RC supply chain, where only the on-site activities are taken into account from all formwork-related activities.

The above-mentioned studies do not take into account the fact that there may be different SCCs for industrial formwork systems and their impact on project performance. Therefore, the objectives of this study are to identify SCCs for industrial formwork systems in the Turkish RC construction industry and to analyze the identified configurations using the VSM method.

\section{Research Methods}

In $\mathrm{RC}$ construction, identification and analysis of SCCs for industrial formwork systems among all stakeholders can improve time, cost, quality, and safety performance. This study intends to identify the SCCs for industrial formwork systems and measure their time performance. In other words, in this study, only the time metric is used to analyze the SCCs' performances. To achieve these objectives, the following tasks were carried out:

(1) Reviewing the literature on formwork supply chains in accordance with the VSM method;

(2) Conducting face-to-face interviews with five practitioners with more than 20 years of 
experience in the Turkish RC construction industry to identify the SCCs for industrial formwork systems;

(3) Performing site visits and field studies to companies involved in the industrial formwork system supply chain to confirm the identified SCCs, and to determine the roles and responsibilities of all stakeholders in these SCCs;

(4) Mapping the processes of the SCCs;

(5) Collecting data from a real-life case study in Turkey, where identified SCCs were implemented by separate formwork orders;
(6) Analyzing data obtained from the case study by VSM method,

(7) Interpreting the findings and investigating the main reasons behind time waste;

(8) Presenting recommendations for future studies to improve the performance of industrial formwork system supply chains.

The tasks performed in this study are shown in Fig. 1.

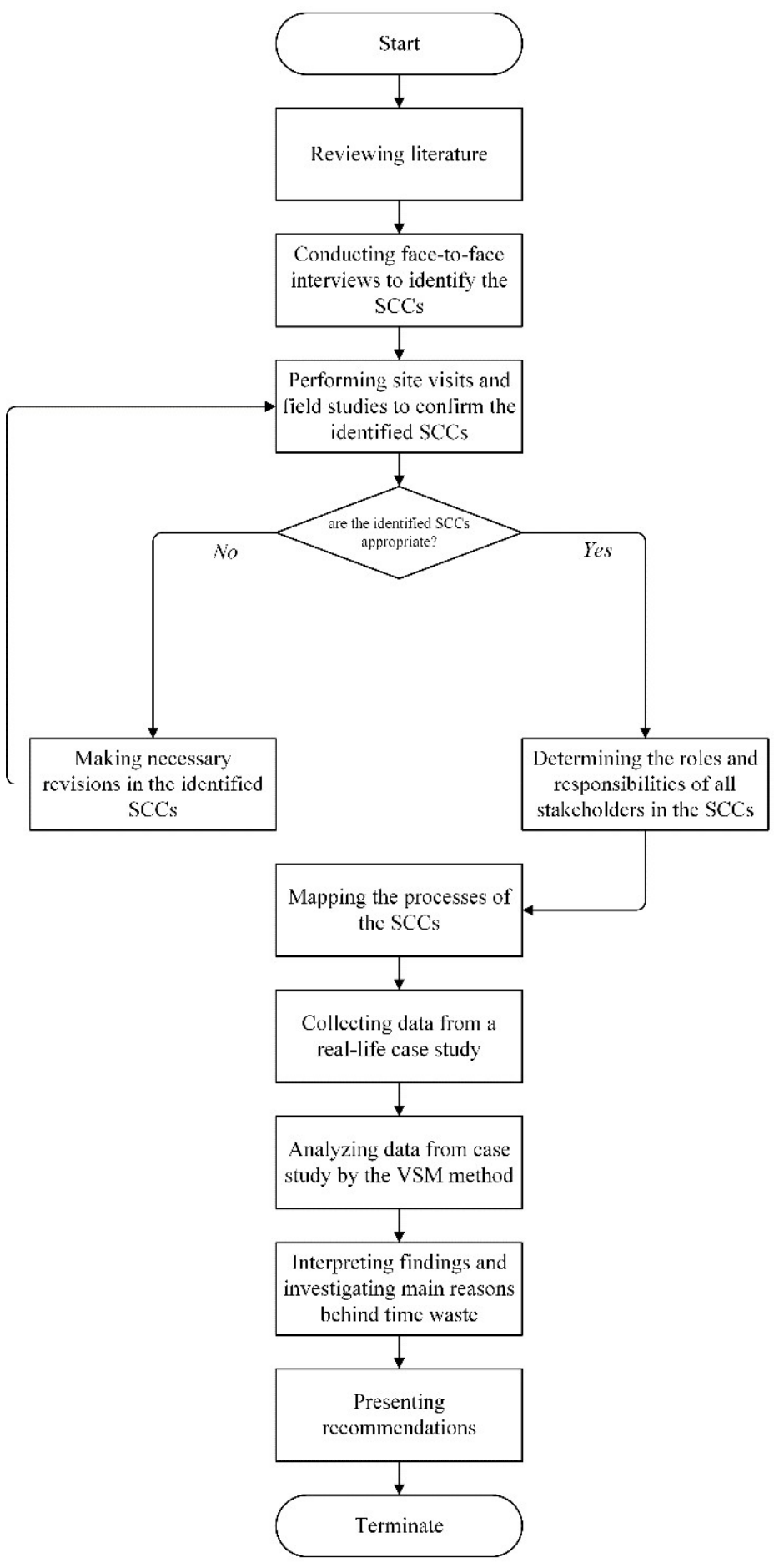

Fig. 1. Research methods 
In order to determine the SCCs used for industrial formwork systems in the Turkish RC construction industry, face-to-face interviews were conducted with five practitioners with more than 20 years of experience in the $\mathrm{RC}$ construction industry. Then, site visits and field studies were performed to companies involved in the industrial formwork system supply chain to confirm the identified configurations and to determine the roles and responsibilities of all stakeholders in these SCCs. The identified SCCs were compared with the observations from the site visits and field studies. In case of differences between the results of the face-to-face interviews and the results of the site visits and field studies, necessary adjustments were made. The revised version of the SCCs was submitted to the practitioners for re-evaluation. After confirming the revised SCCs, the data obtained from these stages were described as process maps and analyzed using the VSM method.

Since the data obtained from the case study were analyzed using the VSM method, this method is briefly described.

The development of VSM has its roots in the philosophy of "Lean Thinking", which was first introduced by Ohno (1988) and further developed by Monden (1993) for Toyota's production system. The key fundamental principles of "Lean Thinking" are the definition of value, the identification of value stream, and the uninterrupted flow of value (Womack and Jones, 1996). In the context of manufacturing, there are three types of operations or activities, which are non-value adding (NVA), valuesupporting (VS), and value-adding (VA) (Monden, 1993). NVA activities produce pure waste and can be eliminated entirely, while VS activities also produce waste, but the elimination of waste requires considerable changes in the production system (Hines and Rich, 1997). Waste is classified into seven types: overproduction, waiting, transport, inappropriate processing, unnecessary inventory, unnecessary movement, and defects (Monden, 1993). As a result, the VSM method is a tool for practitioners and researchers, which can identify and eliminate, if possible, or reduce waste (Hines and Rich, 1997; Arbulu et al., 2003).

The "Value stream", are all the VA and NVA activities required by a specific product, starting with the flow of raw material until delivering it to the customer (Rother and Shook, 1999). In this context, VSM is a process benchmarking technique, which compares the actual performance of an activity with the improved future state of the same activity (Hines et al., 1999). This comparison is achieved by determining the VA and NVA activities in a specific process and measuring the percentage of improvement after waste is eliminated or reduced. Thus, VSM helps to visualize the process flow of activities in a supply chain and to identify the root causes of waste (Hines et al., 1998; Rother and Shook, 1999). In addition, VSM can be visualized with process maps, which describe the material and information flows of the product (Womack and Jones, 1996). More comprehensive information about VSM can be found in Singh et al. (2011)'s study.

After the process maps for the different SCCs were determined, time data for the activities in the SCCs were collected using a real-life case study of an ongoing building project. For this purpose, daily site visits were conducted to the three main stakeholders, namely the engineer, the contractor, and the formwork fabricator (FWF). The time value in days (i.e., lead time and value-added time) for each activity performed at SCCs was determined in collaboration with the team responsible for that activity. For example, the plan and detail activity of the formwork system and related processes were performed by the FWF at each SCC. FWF's design team used specialized company software to record time spent on projects each day. Therefore, value-added time information was obtained for this by the FWF. In addition, the lead time was determined by recording the dates when the FWF received the order from the contractor and the formwork system was delivered to the construction site. Time values were determined similarly for each activity performed by the engineer and contractor in SCCs. In the absence of specialized company software, a logbook was used to measure the time spent on each activity in the SCCs. After analyzing the SCCs using the VSM method, the results were shared with all stakeholders, and revisions were made if necessary. In addition, researchers discussed with stakeholders the reasons for the wasted time of each activity in the SCCs.

\section{Identification of Supply Chain Processes in Industrial Formwork Systems}

Descriptions of the main activities and processes in the industrial formwork system SCCs, respectively, are categorized as follows (Shen, 1992; Terzioglu et al., 2019):

(1) Design of the structural framework:

- Preparation of all necessary documents relevant to the structural framework of the RC structure (e.g., structural type, structural analysis, structural design);

(2) Design of the formwork system:

- Analysis of necessary documents (e.g., type of the project, structural designs, documents and drawings, bill of quantities of RC structural system, method of statements, relevant laws, regulations, and standards prevailing in the country in question, construction schedule and duration regarding the structural system),

- Determination of potential formwork system alternatives considering the project constraints and requirements, and then selection of the most appropriate alternative,

- Determination of the quantity of formwork stock for columns, slabs and walls required to achieve the planned project schedule;

(3) Plan and detail of the formwork system:

- Estimation of the quantity of formwork system components for production planning,

- Preparation of preliminary formwork plans and drawings,

- Preparation of shop drawings of formwork systems,

- Preparation of assembly drawings of formwork systems,

- Preparation of production drawings of formwork systems for non-standard product groups, if necessary, 
- Calculation of the exact quantity of formwork system components;

(4) Production of the formwork system components:

- Control of the raw material stock and, if necessary, order the required raw materials,

- Production of the main components of the selected formwork system in accordance with shop drawings and/or production drawings;

(5) Delivery of the produced formwork system components to contractor:

- Stockyard management to determine available quantities of the formwork system,

- Label formwork system components according to product groups,

- Load trucks according to product groups,

- Control and regulate the weight of trucks and/or containers in accordance with the laws and regulations of the relevant country;

(6) Preparation of the job:

- Unload formwork system components on construction site,

- Arrange and label formwork system components according to product groups,

- Count, store and protect formwork system components on construction site (i.e., inventory management),

- Transfer formwork system components to the designated points on the construction site;

(7) Assembly of the formwork system components for standard and non-standard formwork components;

(8) Installation of the formwork system.

It should be noted that delivery to the construction site and installation of the formwork system components are

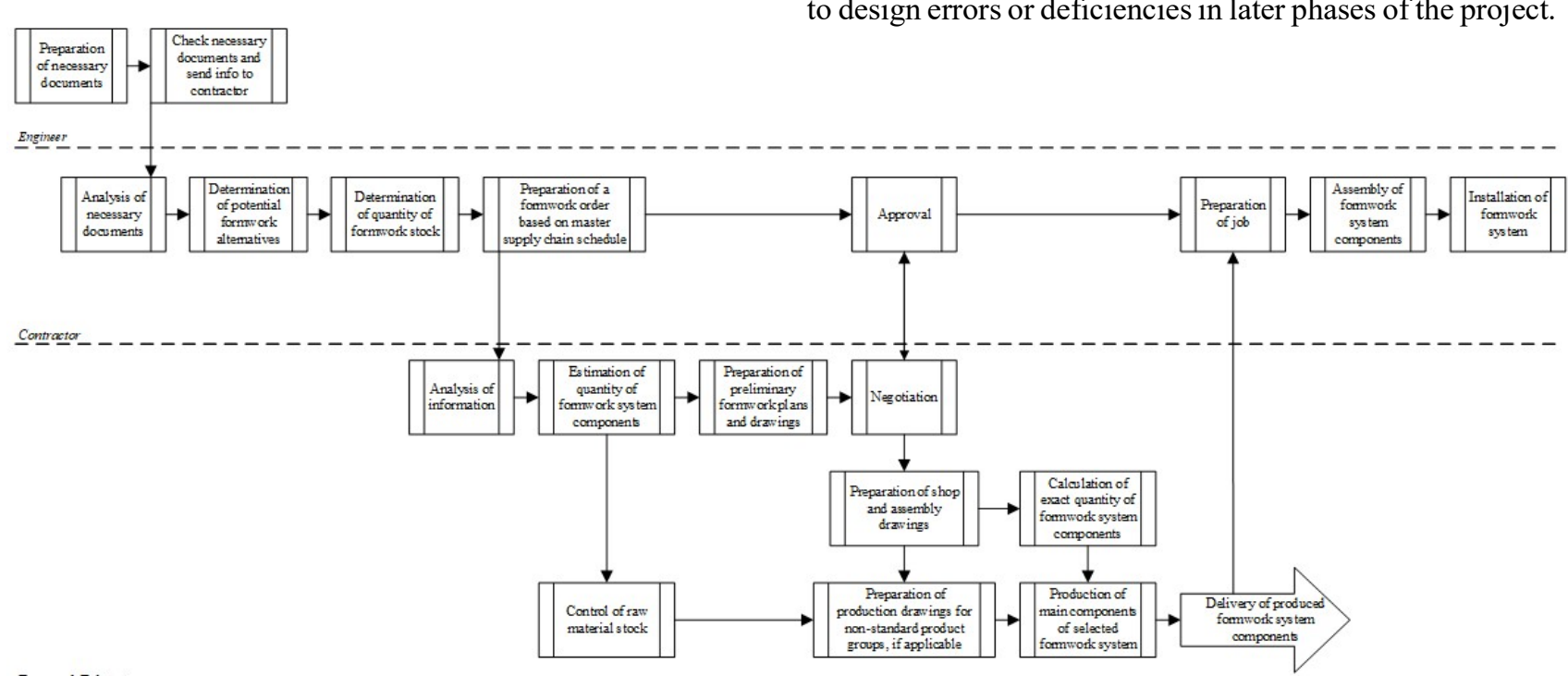

described in this section but not addressed within the scope of this study.

These activities are carried out by engineers, FWFs, and contractors. The roles and responsibilities of the stakeholders in the industrial formwork system supply chain can be combined in different ways depending on the project delivery system, construction method, type of structure, and capacity of the stakeholder (Terzioglu et al., 2019). As a result, different SCCs can be identified and represented by process maps for the industrial formwork system.

The analysis results concluded that there are three SCCs widely used for industrial formwork systems in the Turkish RC construction industry. These configurations are maps identify the roles and responsibilities of stakeholders in the supply chain process as SCC 1, SCC 2, and SCC 3 for industrial formwork systems.

In SCC 1, the contractor determines potential formwork alternatives, selects the most appropriate formwork alternative, and determines the initial quantities of the selected formwork to prepare the project schedule. Therefore, in this configuration, the contractor and its technical team must have the knowledge and professional experience with the industrial formwork systems and the local formwork market situation. The advantage of this configuration could be that if the contractor successfully completes the activities undertaken, the FWF spends less time in the plan and detail of the formwork system, thereby reducing overall lead time. In addition, the contractor may have the necessary formwork system components available in its own inventory to be modified and used in the project, which can reduce additional lead time and cost spent for the production of new formwork system components. The disadvantage of this configuration could be that if the selected formwork system does not exist in the local market, increasing overall lead time. Another disadvantage of this configuration may be the lack of design feedback from other stakeholders in the supply chain, which can improve the quality of the formwork design and reduce rework due to design errors or deficiencies in later phases of the project. presented as process maps in Figs. 2, 3, and 4. The process it may cause rework of design-related activities, thereby

Fig. 2. Supply chain configuration (SCC) 1 


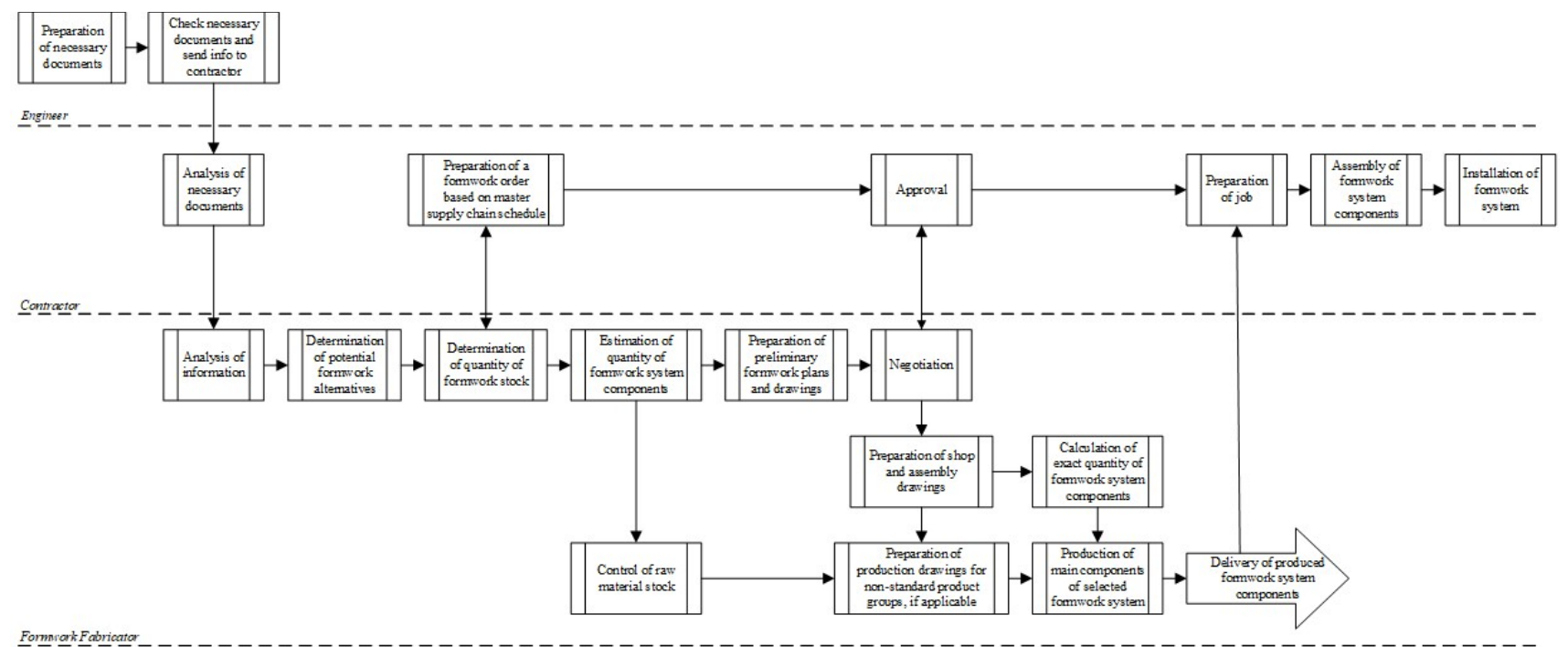

Fig. 3. Supply chain configuration (SCC) 2

In SCC 2, the FWF prepares the design and detailed shop drawings for the formwork, determines initial formwork quantities, develops the project schedule, and performs the formwork fabrication activities. In this configuration, the FWF is considered an expert in the design, plan, and detail of the formwork system. In addition, the FWF is accustomed to work with many contractors on different types of projects and thus often has the experience needed to deal with the complexities of projects. The FWF also provides information to contractors on which alternative formwork systems are appropriate for their projects. Planning the time needed to construct the structural framework is an important task in the management of construction projects. This information is best provided by the FWF due to its expertise and knowledge of the assembly, erection, and striking times of the formwork systems. Ko and Kuo (2019) argued that the integration of the formwork subcontractor (i.e., FWF) into the formwork design process in coordination with other stakeholders could reduce design errors and change orders during construction phases. Ko (2017) highlighted that design quality could be improved by almost $50 \%$ in the early phases of the project, taking into account feedback from all stakeholders on the design. Therefore, the advantage of this configuration is that less time is spent searching for formwork alternatives that are not available on the market or need to be imported from abroad, as the FWF selects alternatives based on the stock of raw material and the local market situation. The disadvantage of this configuration is that the FWF takes over most of the activities and responsibilities, thereby may be overloaded. If there is a delay caused by the FWF, it directly affects the assembly and installation of the formwork system, which may extend the contractor's lead time. Furthermore, if the contractor experiences financial difficulties related to the project budget, it may reject the formwork systems selected by the FWF. Consequently, this situation may lead to additional rework of all activities previously carried out. Therefore, a strong and continuous flow of information must be provided between the contractor and the FWF to ensure that the proposed alternatives meet the needs and requirements of the contractor.

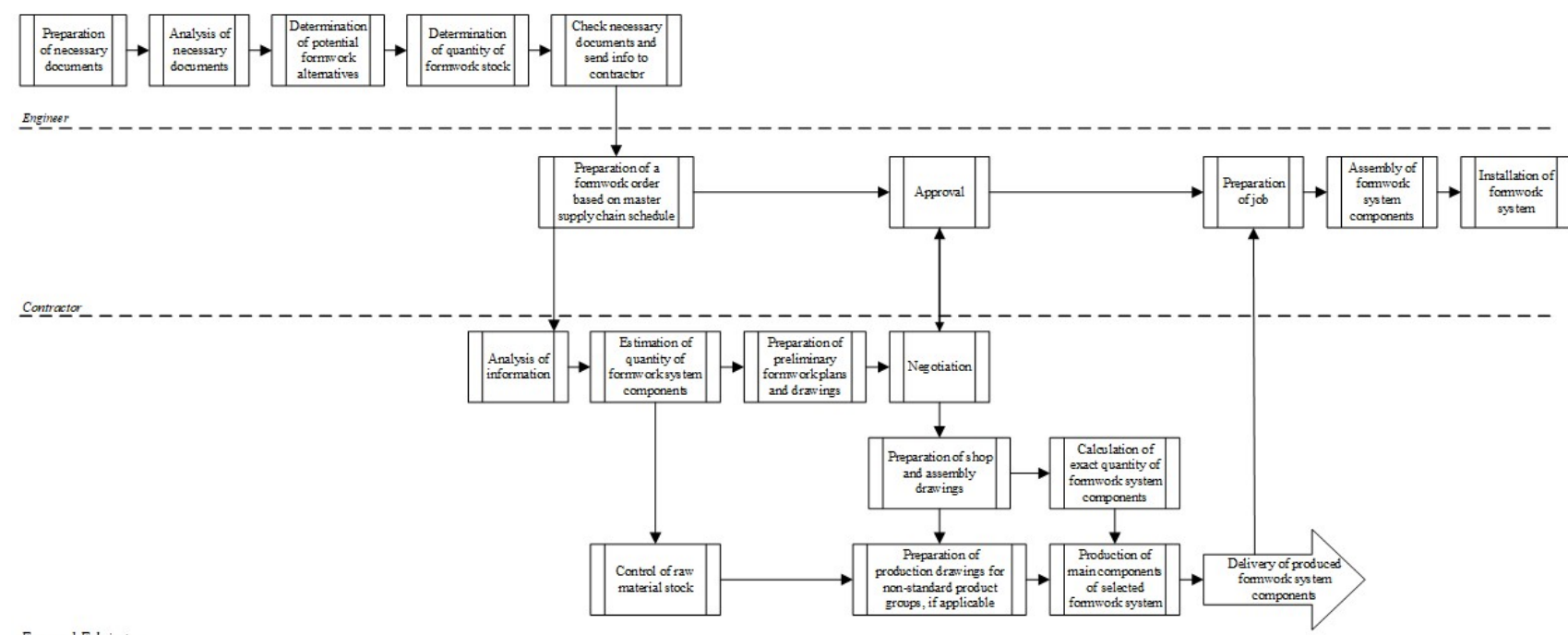

Fig. 4. Supply chain configuration (SCC) 3 
In SCC 3, the engineer prepares the design for the formwork, develops the project schedule, and determines initial formwork quantities. In this configuration, the engineer must have the necessary experience, expertise in formwork systems, and in-house technical capacity in the formwork field. The advantage of this configuration is that since the structural framework is designed by the engineer, the formwork performance in the project can be maximized by pre-selecting the most appropriate formwork system or by making structural design revisions easily. However, some RC structures may have some structural design constraints related to the type of concrete, the type of structural system, or the construction method selected in the project. As a result, these constraints affect the type of formwork system used, hence they have a direct impact on time, cost, productivity, and safety performances of the project (Hanlon and Sanvido, 1995). Therefore, if the engineer has the required technical capacity, the integration of the structural design concept with the available formwork systems at an early phase of the project can be a valuable strategy for reducing rework at a later phase of the project. The disadvantage of this configuration is that the FWF is not directly involved in the activities carried out by the engineer, therefore interruptions and delays in the flow of information between stakeholders may occur, which may have a negative effect on the overall lead time of the supply chain. In addition, if the project budget is exceeded or there is a different opinion about the implementation of the formwork system during the construction phase, the formwork system selected by the engineer may not be accepted by the contractor. Consequently, this situation causes the additional rework of all activities previously carried out.
In summary, the FWF is always responsible for the plan, detail, and fabrication of the formwork system, while the design of the formwork is carried out by different stakeholders. The design of the structural framework and the preparation of the relevant documents are always carried out by the engineer, whereas the contractor always prepares the job, assembly, and installation of the formwork. The activities in the supply chain of the industrial formwork system, which will be carried out by stakeholders in different SCCs, are presented in Table 1.

Table 1. The activities in the industrial formwork system supply chain performed by each stakeholder

\begin{tabular}{cccc}
\hline & \multicolumn{3}{c}{ Activities } \\
\cline { 2 - 4 } Stakeholders & Design & $\begin{array}{c}\text { Plan and } \\
\text { Detail }\end{array}$ & Fabrication \\
\hline Engineer & 3 & - & - \\
Contractor & 1 & - & - \\
Formwork & 2 & $1,2,3$ & $1,2,3$ \\
Fabricator & & - \\
\hline
\end{tabular}

The decision to determine the most appropriate SCC for the project depends on the project characteristics, the project delivery methods, the stakeholders' experience, and their technical, operational, and managerial skills. The characteristics, advantages, and disadvantages of the three industrial formwork system SCCs are summarized in Table 2 .

Table 2. The characteristics, advantages, and disadvantages of the industrial formwork system SCCs

\begin{tabular}{|c|c|c|c|c|}
\hline $\mathrm{SCCs}^{*}$ & Characteristics & Advantages & Disadvantages & Comments \\
\hline 1 & $\begin{array}{c}\text { Contractor designs, } \\
\text { selects formwork } \\
\text { alternatives, and } \\
\text { determines quantities. } \\
\text { FWF prepares details } \\
\text { and supplies formwork. }\end{array}$ & $\begin{array}{l}\text { Less number of cycles, } \\
\text { Less lead time, } \\
\text { Involvement of the } \\
\text { contractor in the design } \\
\text { and scheduling } \\
\text { processes. }\end{array}$ & $\begin{array}{l}\text { High interdependence } \\
\text { between the contractor } \\
\text { and the FWF, } \\
\text { High rework. }\end{array}$ & $\begin{array}{l}\text { Preferred if the } \\
\text { contractor is able to } \\
\text { execute the design of } \\
\text { the formwork. }\end{array}$ \\
\hline
\end{tabular}

Less number of cycles,

Less lead time,

FWF designs, selects formwork alternatives, 2 determines quantities, prepares details and supplies formwork.
Early involvement of

FWF in design phase,

Less rework,

Least the

interdependence of the stakeholders.
High mutual dependence between the contractor and the FWF,

Most of the activities are performed by the FWF.
Preferred if the FWF is able to execute the design of the formwork.
Less number of cycles, Less lead time, Involvement of the engineer in the design and scheduling processes.
Engineer designs selects formwork alternatives, and 3 determines quantities. FWF prepares details and supplies formwork.
Requires good communication and continuous flow of information between all stakeholders, High rework.
Preferred if the engineer

is able to execute the design of the formwork. 


\section{Analysis of SCCs for industrial formwork systems}

The performance and efficiency of a formwork supply chain can be measured using time, cost, and quality parameters. The aim of the analysis of the SCCs is to determine time waste, to identify the reasons for the waste, and to improve the performance parameters. Solving the problems of each SCC and selecting the most suitable solutions for the project can increase the efficiency of the project performance parameters. In this study, only the time metric is examined using the VSM method to quantify lead time, value-added time, and non-value-added time for all the activities in the industrial formwork system SCCs.

Lead time represents the time elapsed between the start and completion of an activity, which includes processing time, set-up time, movement time, and wait time (Arbulu et al., 2003). In addition, the total lead time is defined as the time elapsed from receiving the order of the product to its delivery to the customer (Nallusamy and Ahamed, 2017). In the context of this study, lead time is the time actually measured from the beginning to the completion of the design, plan, and detail, production, delivery, preparation, assembly, and installation of the formwork activities, while value-added time is the time spent on improving the outcome of an activity. Koskela (1992) stated that only the process time is part of a VA activity, but Polat and Ballard (2004) explained that not all process time is value-added. NVA activities are incorrectly planned processes that do not use resources effectively and generate waste in the supply chain (Monden, 1993; Hines and Rich, 1997). In this study, lead time and value-added time are compared with each other, and non-value-added time is determined and eliminated. As a result, the lead time of the overall supply chain can be decreased.

The performance analysis of SCC 1 and the results are presented in Fig. 5. Based on the results, the total valueadded time is 35 days for all activities, while the total lead time is 68 days, which means that $49 \%$ of the total time is wasted. Value-added time (in days), lead time (in days), and wasted time (\%) for all activities in the SCC 1 are presented in Table 3.

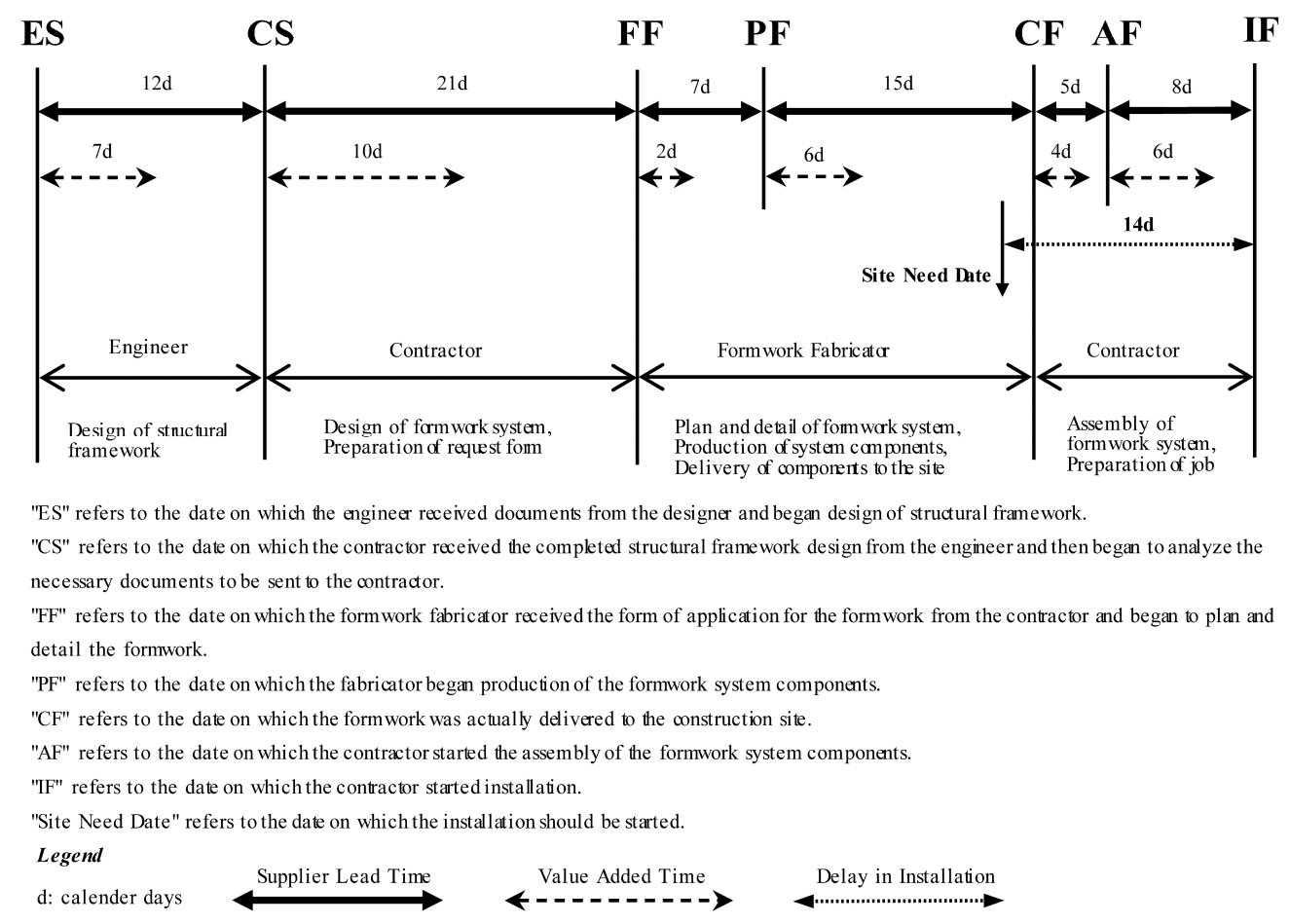

Fig. 5. The results of the performance analysis of SCC 1

Table 3. Time information for all activities in the SCC 1

\begin{tabular}{|c|c|c|c|}
\hline Formwork-Related Activities & $\begin{array}{l}\text { Value-Added } \\
\text { Time (days) }\end{array}$ & $\begin{array}{l}\text { Lead Time } \\
\text { (days) }\end{array}$ & $\begin{array}{c}\text { Wasted } \\
\text { Time (\%) }\end{array}$ \\
\hline Design of structural framework & 7 & 12 & 42 \\
\hline Design of formwork system, preparation of request form & 10 & 21 & 52 \\
\hline Plan and detail of formwork system & 2 & 7 & 71 \\
\hline Production of system components, delivery of components to the site & 6 & 15 & 60 \\
\hline Preparation of job & 4 & 5 & 20 \\
\hline Assembly of formwork system & 6 & 8 & 25 \\
\hline Total Values & 35 & 68 & 49 \\
\hline
\end{tabular}


The results of the performance analysis of SCC 2 are presented in Fig. 6. The SCC 2 starts with the design of the structural framework by the engineer. Similar to SCC 1, while the lead time for this activity is 12 days, and the value-added time is seven days. The contractor's lead time for assembly of the formwork system components and preparation of the job is 13 days. Compared to SCC 1 , it can be observed that the contractor's lead time for these activities is reduced by eight days in this configuration, since the contractor analyzes the documents received from the engineer and then sends them to the FWF. In other words, the contractor does not design the formwork solution in this configuration.

The main difference between SCC 2 and others is that the FWF is involved early in the design phase of the formwork. The FWF selects the formwork alternatives and determines the quantity of the formwork by exchanging information with the contractor's technical and procurement departments. In SCC 2, "concurrent design" approach proposed by Ko and Kuo (2019), which enables the incorporation and integration of design knowledge of all stakeholders at an early phase, is adopted. In general, the FWF has better stock and quantity knowledge and uses standardized methods to optimize the formwork solution before negotiations start so that rework can be reduced. Once negotiations are started between the FWF and the contractor, non-standardized formwork solutions can be eliminated, and solutions can also be better adapted, which may further reduce the waste and rework during the design phase of formwork. In this configuration, as the nonstandardized formwork components are reduced by the early involvement of the FWF, the lead time for plan, detail and production of the formwork is also reduced to 16 days $(7 d+9 d)$. The value-added time spent on design, plan, detail, and production of the formwork is 11 days $(5 d+6 d)$, which is three days longer than in SCC 1, since the FWF designs, plans and details of the formwork in parallel and in coordination with the contractor.

Based on Fig. 6, although the value-added time for assembly of formwork system is six days, the actual time elapsed for that activity is seven days. In this case, the delay is reduced by one day, compared to SCC 1, due to the reduction of non-standard formwork components, which may result in rework. According to Figure 6, 38 days are spent on all activities in the supply chain, and the total supply chain time is 53 days. The results revealed that $28 \%$ of the total time is wasted, and this configuration provides a $21 \%$ more reduction in non-value-added activities compared to SCC 1. Value-added time (in days), lead time (in days), and wasted time (\%) for all activities in the SCC 2 are presented in Table 4.

The results of the performance analysis of SCC 3 are presented in Fig. 7. The SCC 3 starts with the design of the structural framework by the engineer. The main difference between SCC 3 and others is that the design of the formwork system is performed by the engineer in parallel with the design of the structural framework. The structural framework is optimized by the engineer in order to fit the standardized formwork systems. However, it should be noted that this process requires a high level of expertise, inhouse capacity, and knowledge about formwork systems. The lead time for activities that are the responsibility of the engineer is 20 days, while the value-added time for these activities is 11 days. The reason for the waste in these activities is the redesign of the structural framework and the formwork system in order to maximize output in later phases. The contractor analyzes the documents received from the engineer and then sends them to the FWF.
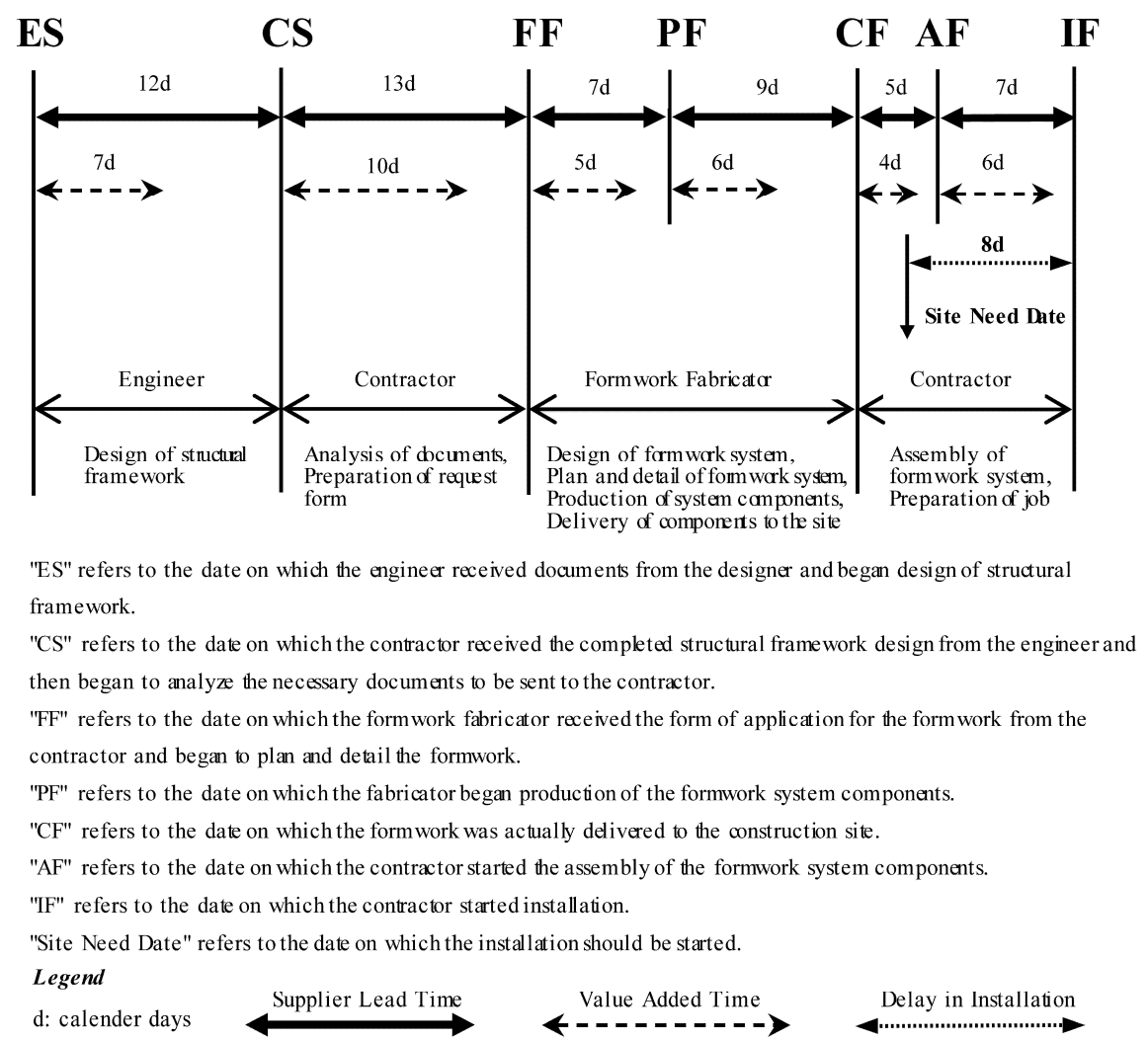

Fig. 6. The results of the performance analysis of SCC 2 
Table 4. Time information for all activities in the SCC 2

\begin{tabular}{cccc}
\hline Formwork-Related Activities & $\begin{array}{c}\text { Value-Added } \\
\text { Time (days) }\end{array}$ & $\begin{array}{c}\text { Lead Time } \\
\text { (days) }\end{array}$ & $\begin{array}{c}\text { Wasted } \\
\text { Time (\%) }\end{array}$ \\
\hline Design of structural framework & 7 & 12 & 42 \\
Analysis of documents, and preparation of request form & 10 & 13 & 23 \\
Design, plan and detail of formwork system & 5 & 7 & 29 \\
Production of system components, delivery of components to the site & 6 & 9 & 33 \\
Preparation of job & 4 & 5 & 20 \\
Assembly of formwork system & 6 & 7 & 14 \\
Total Values & $\mathbf{3 8}$ & $\mathbf{5 3}$ & $\mathbf{2 8}$ \\
\hline
\end{tabular}

The lead time of the contractor for these activities is 15 days, while the value-added time for the same activities is seven days. If the cost of the formwork systems selected by the engineer exceeds the project budget, the contractor may reject these systems. In this case, the formwork system is redesigned before the contractor sends the documents to the FWF, which may increase the total lead time. In addition, in the absence of the FWF's involvement, the quantity of formwork systems determined by the engineer may be miscalculated, which might lead to overproduction. As a result, overproduction may result in waste such as additional cost and delivery time (Hong-Minh et al., 1999). The FWF spends ten days on the plan and detail of the formwork system and 12 days on the production of the formwork system components. Although the total lead time of the FWF for these activities (22d) is the same in SCC 1 and SCC 3, the non-value-added time for the same activities is lower in SCC 3. The reason for the relatively small amount of waste is associated with the development of the formwork design by the engineer in previous phases. On the other hand, compared to SCC 2, the waste in plan and detail of the formwork system activities in SCC 3 is $21 \%$ higher since the formwork design performed by the engineer does not always fit the standard formwork components of the FWF.

Based on Fig. 7, the time elapsed for assembly of formwork system are similar to SCC 1. Although the valueadded time for assembly of the formwork system is 6 days, the actual time spent on this activity is 8 days. Total valueadded time for all activities is 39 days, while total lead time is 71 days, which means that $45 \%$ of total time is wasted. The results revealed that this configuration is $4 \%$ less than SCC 1 and $17 \%$ more than SCC 2 in terms of wasted time. Value-added time (in days), lead time (in days), and wasted time $(\%)$ for all activities in the SCC 3 are presented in Table 5 .

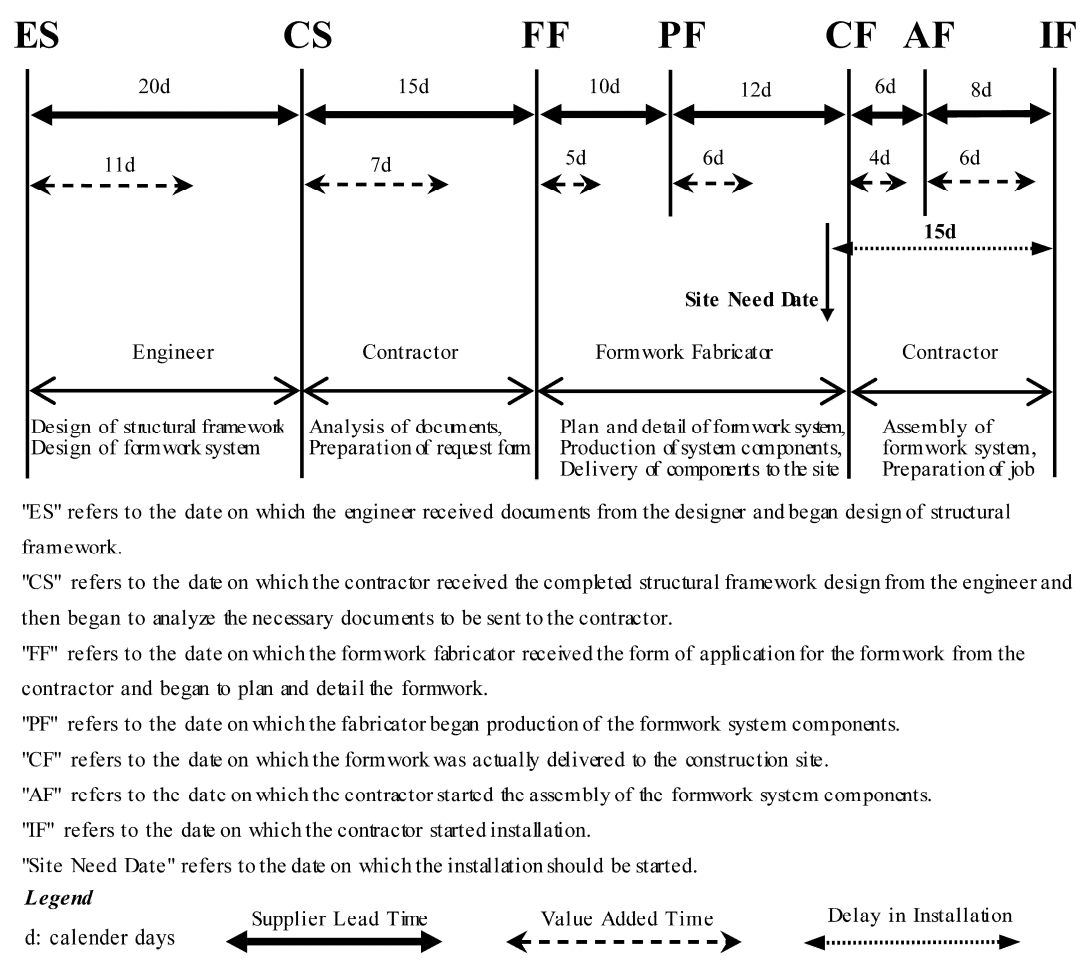

Fig. 7. The results of the performance analysis of SCC 3 
Table 5. Time information for all activities in the SCC 3

\begin{tabular}{cccc}
\hline Formwork-Related Activities & $\begin{array}{c}\text { Value-Added } \\
\text { Time (days) }\end{array}$ & $\begin{array}{c}\text { Lead Time } \\
(\text { days })\end{array}$ & $\begin{array}{c}\text { Wasted } \\
\text { Time }(\%)\end{array}$ \\
\hline $\begin{array}{c}\text { Design structural framework and formwork system } \\
\text { Analysis of documents, and preparation of request form }\end{array}$ & 11 & 20 & 45 \\
Plan and detail formwork system & 7 & 15 & 53 \\
Production of system components, delivery of components to the site & 6 & 10 & 50 \\
Preparation of job & 4 & 6 & 33 \\
Assembly of formwork system & 6 & $\mathbf{3 9}$ & $\mathbf{7 1}$ \\
Total Values & & $\mathbf{4 5}$ \\
\hline
\end{tabular}

\section{Evaluation of industrial formwork system SCCs}

Early stakeholder involvement is a key aspect of lean construction, which can reduce waste in the supply chain (Pheng et al., 2015; Wondimu et al., 2016). The success of a project is considerably influenced by the early involvement of stakeholders, as group decisions taken at the early phase of the project reduce the risk of change at the later phases of the project and also help to improve the design and construction processes. In addition, early involvement of all stakeholders at the design phase can improve the constructability of the design, thereby allowing more cost-effective use of resources in the subsequent phases of the construction project (Forbes and Ahmed, 2010).

The most common SCC for the industrial formwork system in the Turkish construction industry is SCC 2, in which the FWF is involved early in the design phase. SCC 3 requires the engineer to be an expert and knowledgeable in the design of formwork systems. However, in the Turkish construction industry, the engineer specializes mainly in the design of structural frameworks and is less specialized in the design of formwork systems. Therefore, SCC 3 is the least commonly used SCC for the industrial formwork system in Turkey. On the other hand, SCC 1 is preferred for the industrial formwork system if the contractor has inhouse capacity for the design of the formwork systems.

In summary, the different SCCs for the industrial formwork systems were analyzed using the VSM method, and percentages of time waste were determined by comparing lead time and value-added time for formworkrelated activities. SCC 1 has a total waste of $49 \%$, SCC 2 has $28 \%$, and SCC 3 has $45 \%$. The results indicated that the total waste percentage in SCC 2 is lower than the total waste percentages in SCC 1 and 3, and the total lead time in SCC 2 is only 53 days. The major factor for the improved performance of SCC 2 is the early involvement of the FWF in the design phase, resulting in less rework in the later phases. The main reasons for the wasted time in the formwork-related activities of each industrial formwork system supply chain are summarized in Tables 6,7 , and 8 .

Table 6. Reasons for wasted time in the activities of SCC 1

\begin{tabular}{cc}
\hline Formwork-Related Activities & Reasons for Wasted Time \\
\hline Design of the structural framework & Lack of coordination among stakeholders. \\
$\begin{array}{c}\text { Design of the formwork system } \\
\text { Preparation of request form }\end{array}$ & $\begin{array}{c}\text { Lack of information and data flow between the FWF and the } \\
\text { contractor, }\end{array}$ \\
$\begin{array}{c}\text { Lack of standardized data format exchange system. } \\
\text { procurement departments, }\end{array}$ \\
\hline $\begin{array}{c}\text { Production of the formwork system components } \\
\text { Delivery of the components to the construction site }\end{array}$ & $\begin{array}{c}\text { Lack of standardized methods for non-stand componts and } \\
\text { orders. }\end{array}$ \\
\hline Preparation of the job & $\begin{array}{c}\text { Inflexible production systems. } \\
\text { Assembly of the formwork system }\end{array}$ \\
\hline
\end{tabular}


Table 7. Reasons for wasted time in the activities of SCC 2

\begin{tabular}{cr}
\hline Formwork-Related Activities & Reasons for Wasted Time \\
\hline Design of structural framework & Lack of coordination among stakeholders. \\
$\begin{array}{c}\text { Analysis of documents } \\
\text { Preparation of request form }\end{array}$ & $\begin{array}{c}\text { Lack of information and data flow among all stakeholders, } \\
\text { Lack of standardized data format exchange system. }\end{array}$ \\
\hline Design, plan and detail of the formwork system & Lack of standardized methods for orders. \\
\hline $\begin{array}{c}\text { Production of the formwork system components, } \\
\text { Delivery of the components to the construction site }\end{array}$ & Inflexible production systems. \\
\hline Preparation of the job & Inadequate inventory management. \\
\hline Assembly of the formwork system & Rework due to worker mistakes.
\end{tabular}

Table 8. Reasons for wasted time in the activities of SCC 3

\begin{tabular}{cc}
\hline Formwork-Related Activities & Reasons for Wasted Time \\
\hline $\begin{array}{c}\text { Design of the structural framework and the } \\
\text { formwork system }\end{array}$ & Lack of coordination between the engineer and the contractor. \\
\hline $\begin{array}{c}\text { Preparation of request form } \\
\text { Plan and detail of the formwork system }\end{array}$ & $\begin{array}{c}\text { Lack of information and data flow between the contractor and } \\
\text { the engineer, }\end{array}$ \\
Lack of standardized data format exchange system.
\end{tabular}

Production of the formwork system components,

Delivery of the components to the construction site

Inflexible production systems.

\begin{tabular}{cc}
\hline Preparation of the job & Inadequate inventory management. \\
\hline Assembly of the formwork system & Lack of expertise of workers on non-standard components, \\
& Rework due to worker mistakes. \\
\hline
\end{tabular}

Based on Tables 6, 7, and 8, it can be deduced that, while the primary reasons for wasted time in all SCCs are mostly the same, the activities where they occur and their amounts can differ from one SCC to another. Moreover, the common reasons for wasted time in all SCCs are lack of coordination and lack of information and data flow among stakeholders, lack of standardized data format exchange system, lack of standardized methods for orders, inflexible production systems, inadequate inventory management, and rework due to worker mistakes. In this context, the performance of all SCC can be improved by standardized information flow, standardized solutions for non-standard problems, accurate data transfer, flexible production systems, effective inventory management, and better coordination between stakeholders.

\section{Conclusions}

Formwork is one of the most critical components in $\mathrm{RC}$ structures, and industrial formwork system supply chain performs better than traditional formwork system supply chain in terms of shorter lead time and less time waste. Time and material waste in the RC supply chain can be reduced through a lean construction approach. Several researchers have focused on the lean design of formwork and its application on the construction site to improve the performance of RC construction projects. However, these studies neglected the relationship of roles and responsibilities between stakeholders of the industrial formwork system supply chain and its impact on the supply chain performance. The aim of this study is to fill this crucial research gap.

The roles and responsibilities of the stakeholders in the industrial formwork system supply chain can be represented by different process maps. In order to determine the SCCs used for industrial formwork systems in the Turkish RC construction industry, face-to-face interviews, site visits, and field studies were conducted. The data obtained from these stages were described as process maps and analyzed using the VSM method. The analysis results revealed that there are three SCCs commonly used for industrial formwork systems in the Turkish RC construction industry. In order to investigate the performance of these SCCs and the main reasons behind time waste for each SCC, an ongoing building project, where $500 \mathrm{~m}^{2}$ of industrial wall formwork would be used, was examined as a real-life case study.

The analysis results indicated that the industrial formwork system SCC, where the FWF was involved early (SCC 2) with the engineer and contractor at the design phase of the project, had higher performance than other SCCs. The results also concluded that the expertise of the FWF is an important and effective factor in the performance of the industrial formwork system supply chain and is also necessary for the design, plan and detail, and production of the formwork systems. Moreover, time and material waste 
in the industrial formwork system supply chain can be further reduced by standardized information flow, standardized solutions for non-standard problems, accurate data transfer, flexible production systems, effective inventory management, and better coordination between stakeholders. As a result, SCC 2, which can improve time, cost, quality, and safety performance of projects, is proposed for use in the construction industry.

There are some limitations to this study. First, the industrial formwork systems SCCs in this study represent the roles and responsibilities of the stakeholders in building construction projects. Identification of industrial formwork systems SCCs for infrastructure and industrial construction projects, as well as verifications and comparisons with the findings of this study, can be used to perform a more comprehensive study. Second, the activities "delivery to the construction site" and "installation of the formwork system components" were not analyzed within the scope of this study.

In future studies, the performance of the formwork supply chain can be examined by integrating "Building Information Modelling" into the supply chain processes. In addition, different SCCs can be defined and analyzed for the industrial formwork systems, taking into account factors such as the project delivery system, construction method, type of structure, and capacity of the stakeholder.

\section{References}

Abou Ibrahim, H. A. and Hamzeh, F. R. (2015). Expected lean effects of advanced high-rise formwork systems. IGLC, $23^{\text {rd }}$ Annual Conference of the International Group for Lean Construction, Perth, Australia, 83-92. http://dx.doi.org/10.13140/RG.2.1.2338.0326

Arbulu, R. J., Tommelein, I. D., Walsh, K., and Hershauer, J. (2003). Value stream analysis of a re-engineered construction supply chain. Building Research and Information, 31(2), 161-171. http://dx.doi.org/10.1080/09613210301993

Barbosa , A., Gambatese, J., Das, A., and Pestana, A. C. (2014). Mapped workflow for safety and reliability assessments of use and re-use of formwork. Construction Research Congress: Construction in a global network, Atlanta, Georgia. http://dx.doi.org/10.1061/9780784413517.186

Elbeltagi, E., Hosny, O., Elhakeem, A., Abdelrazek, M., and El-Abbasy, M. (2012). Fuzzy logic model for selection of vertical formwork systems. Journal of Construction Engineering and Management, 138(7), 832-840. https://doi.org/10.1061/(ASCE)CO.19437862.0000490

Forbes, L. H. and Ahmed, S. M. (2010). Modern Construction: Lean Project Delivery and Integrated Practices, CRC Press, Boca Raton, FL. https://doi.org/10.1201/b10260

Hanlon, E. J. and Sanvido, V. E. (1995). Constructability information classification scheme. Journal of Construction Engineering and Management, 121(4), 337-345. https://doi.org/10.1061/(ASCE)07339364(1995)121:4(337)

Hawkins, W., Herrmann, M., Ibell, T., Kromoser, B., Michaelski, A., Orr, J., Pedreschi, R., Pronk, A. D. C., Schipper, R., Shepherd, P., Veenendaal, D., Wansdronk, R., and West, M. (2016). Flexible formwork technologies: a state-of-the-art review. Structural Concrete, 17(6), 911-935. https://doi.org/10.1002/suco.201600117
Hines, P. and Rich, N. (1997). The seven value stream mapping tools. International Journal of Operations and Product Management, 17(1), 46-64. https://doi.org/10.1108/01443579710157989

Hines, P., Rich, N., Bicheno, J., Brunt, D., Taylor, D., Butterworth, C., and Sullivan, J. (1998). Value stream management. International Journal of Logistics Management, 9(1), 25-42. https://doi.org/10.1108/09574099810805726

Hines, P., Rich, N., and Esain, A. (1999). Value stream mapping: a distribution industry application. Benchmarking: An International Journal, 6(1), 60-77. https://doi.org/10.1108/14635779910258157

Hong-Minh, S. M., Barker, R., and Naim, M. M. (1999). Construction supply chain trend analysis. Proceedings IGLC-7, University of California, Berkeley, CA, 85-96.

Jarkas, A. M. (2017). Beamless or beam-supported building floors: is buildability knowledge the missing link to improving productivity?. Engineering, Construction and Architectural Management, 24(3), 537-552. https://doi.org/10.1108/ECAM-11-2014-0147

Kannan, M. and Santhi, M. (2018). Automated constructability rating framework for concrete formwork systems using building information modelling. Asian Journal of Civil Engineering, 19 (4), 387-413. https://doi.org/10.1007/s42107-018-0026-3

Karke, S. M. and Kumathekar, M. B. (2014). Comparison of the use of traditional and modern formwork systems. Civil Engineering Systems and Sustainable Innovations, in Mishra, G.C. (Ed.), Excellent Publishing House, New Delhi, India, 348-351.

Ko, C. H., Wang, W. C., and Kuo, J. D. (2011). Improving formwork engineering using the Toyota way. Journal of Engineering, Project, and Production Management, 1(1), 13-27.

http://doi.org/10.32738/JEPPM.201107.0003

Ko, C. H. and Kuo, J. D. (2015). Making formwork construction lean. Journal of Civil Engineering and Management, 21(4), 444-458. https://doi.org/10.3846/13923730.2014.890655

Ko, C. H. (2017). Lean building design model. Procedia Engineering, 182, 329-334. https://doi.org/10.1016/j.proeng.2017.03.104

Ko, C. H. and Kuo, J. D. (2019). Making formwork design lean. Journal of Engineering, Project and Production Management, 9(1), 29-47. https://doi.org/10.2478/jeppm-2019-0005

Ko, C. H. and Kuo, J. D. (2020). Improving formwork engineering using lean tools.9th International Conference on Engineering, Project, and Production Management, 312(02007), Section: Theories and Applications of Project Management, MATEC Web Conferences. https://doi.org/10.1051/matecconf/202031202007

Koskela, L. (1992). Application of the new production philosophy to construction. CIFE, Technical Report \#72, Stanford University, CA. Retrieved from http://purl.stanford.edu/kh328x t3298 on March 7, 2021.

Krawczynska-Piechna, A. (2016). An analysis of the decisive criteria in formwork selection problem. Archives of Civil Engineering, 62(1), 185-196. http://dx.doi.org/10.1515/ace-2015-0060

Krawczyńska-Piechna, A. (2017). Comprehensive approach to efficient planning of formwork utilization 
on the construction site. Procedia Engineering, 182, 366-372.

https://doi.org/10.1016/j.proeng.2017.03.114

Monden, Y. (1993). Toyota Production System: an integrated approach to just-in-time, Industrial Engineering and Management Press, Norcross, GA.

Nallusamy, S. and Adil Ahamed, M. (2017). Implementation of lean tools in an automotive industry for productivity enhancement - a case study. International Journal of Engineering Research in Africa, 29, 175-185.

https://doi.org/10.4028/www.scientific.net/JERA.29.1 75

Nguyen, L. D. and Nguyen, H. T. (2013). Relationship between building floor and construction labor productivity: a case of structural work. Engineering, Construction and Architectural Management, 20(6), 563-575. https://doi.org/10.1108/ECAM-03-20120034

Ohno, T. (1988). The Toyota Production System: Beyond Large-Scale Production, Productivity Press, Portland, OR.

Pheng, L. S., Gao, S., and Lin, J. L. (2015). Converging early contractor involvement (ECI) and lean construction practices for productivity enhancement. International Journal of Productivity and Performance Management, 64(6), 831-852.

https://doi.org/10.1108/IJPPM-02-2014-0018

Pheng, L. S., Gao, S., and Peter, L. K. W. (2016). Using lean principles to reduce wastes in the concreting supply chain. International Journal of Construction Project Management, 8(1), 3-23.

Polat, G. and Ballard, G. (2004). Waste in Turkish construction: need for lean construction techniques. Proceeding 12th Annual Conference of the International Group for Lean Construction, Elsinore, Denmark.

Rosenbaum, S., Toledo, M., and González, V. (2014). Improving environmental and production performance in construction projects using value-stream mapping: case study. Journal of Construction Engineering and Management, 140(2), 1-11.

https://doi.org/10.1061/(ASCE)CO.19437862.0000793

Rother, M. and Shook, J. (1999), Learning to see: value stream mapping to add value and eliminate MUDA, The Lean Enterprise Institute, Brookline, MA.

Samarakoon, S., Vilke, T. G., Stangeland, O. M., Ellefsen, E., Katazina, D., and Ratnayake, R. M. C. (2016). Assessment of value stream of formwork preparation process in prefabricating reinforced concrete elements. Proceedings of the International RILEM Conference Materials, Systems and Structures in Civil Engineering, Conference Segment on Fresh Concrete, Lyngby, Denmark.

Shen, J. F. (1992). Formwork Engineering, Shen, J.F, Taipei, Taiwan.

Shin, Y., Kim, T., Cho, H. H., and Kang, K. I. (2012). A formwork method selection model based on boosted decision trees in tall building construction. Automation in Construction, 23, 47-54. https://doi.org/10.1016/j.autcon.2011.12.007

Singh, B., Garg, S. K., and Sharma, S. K. (2011). Value stream mapping: literature review and implications for Indian industry. International Journal of Advanced Manufacturing Technology, 53, 799-809. http://dx.doi.org/10.1007/s00170-010-2860-7
Sudhakar, N., Vishnuvardhan, K., and Babu, K. T. (2017). Value stream mapping in construction for improving productivity. International Journal of Scientific Research in Civil Engineering, 2(1), 5-8.

Terzioglu, T., Polat G., and Turkoglu, H. (2019). Traditional vs. industrial formwork system supply chains. International Civil Engineering and Architecture Conference, Trabzon, Turkey, 87-97.

Vilventhan, A., Ram, V. and Sugumaran, S. (2019). Value stream mapping for identification and assessment of material waste in construction: a case study. Waste Management and Research, 37(8), 815-825. https://doi.org/10.1177\%2F0734242X19855429

Wang, S., Tang, J., Zou, Y., and Zhou, Q. (2020). Research on production process optimization of precast concrete component factory based on value stream mapping. Engineering, Construction and Architectural Management, 27(4), 850-871. https://doi.org/10.1108/ECAM-10-2018-0455

Womack, J. P. and Jones, D. T. (1996). Lean thinking: banish waste and create wealth in your corporation, Simon \& Schuster, New York, NY.

Wondimu, P. A., Hosseini, A., Lohne, J., Hailemichael, E., and Lædre, O. (2016). Early contractor involvement in public infrastructure projects. Proceedings of 24 th Annual Conference International Group for Lean Construction, Boston, MA, 13-22.

Yunus, R., Noor, S. R. M., Mazlan, S. M. S. S., Hasmori, M. F., and Masrom, M. A. N. (2018). Lean construction in industrialised building system (IBS) implementation: a case study. Sustainable Construction and Building Technology, Penerbit UTHM, 1-17.

Zayed, T. and Mohamed, E. (2014). A case productivity model for automatic climbing system", Engineering, Construction and Architectural Management, 21(1), 33-50. https://doi.org/10.1108/ECAM-02-2012-0015

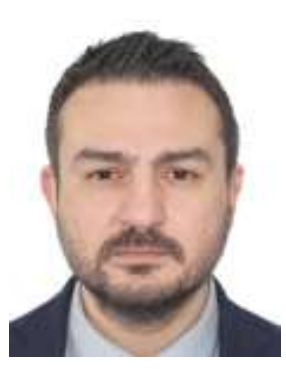

Taylan Terzioglu is a Ph.D. candidate at Istanbul Technical University's Department of Civil Engineering. His main research interests include formwork engineering, decision support techniques, optimization and lean construction. He has more than 15 years of experience as a technical and sales manager at an international formwork and scaffolding engineering company.

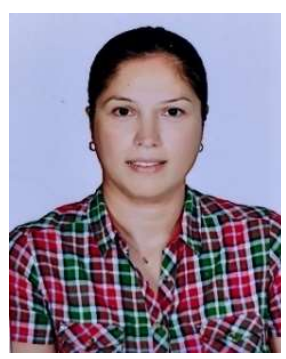

Dr. Gul Polat is Professor of Civil Engineering at Istanbul Technical University. She conducted her Ph.D. studies at Istanbul Technical University and Illinois Institute of Technology in Chicago. Her main research interests include lean construction, decision support techniques, resource management, marketing management, risk management, off-site fabrication, and most aspects of construction management. She has been involved in several research projects funded by different agencies. Her research work over the years has resulted in 156 technical papers in refereed journals and proceedings. Dr. Polat is 
currently serving on the editorial board of an international journal.

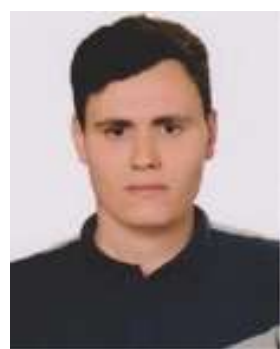

Harun Turkoglu is a Ph.D. candidate and research assistant at Istanbul Technical University's Department of Civil Engineering. His main research interests include scheduling, resource management, decision support techniques, bidding strategies, and most aspects of construction management. His research work over the years has resulted in 36 technical papers in refereed international journals and in peer reviewed conference proceedings. 